\title{
Credit Hour System and Student Workload at Alexandria University: a possible paradigm shift
}

\author{
Alsaeed Alshamy* \\ doi: http://dx.doi.org/10.18543/tjhe-4(2)-2017pp277-309
}

\begin{abstract}
The study aims at investigating the perceptions of both academics and students on student workload in Credit Hour System at the Faculty of Education at Alexandria University (Egypt). It uses the wider international experience of higher education reform, including Tuning Africa Project - II, to propose implications for policy and practice on how the real work hours needed by a student to achieve the learning outcomes specified in the curriculum and to pass a course or module are adequately estimated and to contribute to the definition of the basis of a Credit System for Africa. The data have been collected through questionnaires administered to 26 participants: 11 academics (one academic per course) and 15 students (each student surveyed 11 times across all courses of the Professional Diploma in Education). The main findings show significant differences between the perceptions of academics and students on student workload almost across all courses, where students' estimation of the number of hours needed to complete the independent work during the semester were much higher than that of academics except for fieldwork (site visits). The independent workload as estimated by academics is $62 \%$ of students' estimation. Significant differences were found between the perceptions of students on the number of hours required for each type of independent work across different courses except "preparation and follow-up work for scheduled classes". The highest average of estimations of the number of hours was given to course N. 11 (World Trends in Quality Assurance Systems); whereas the lowest average was given to course N. 5 (Assessment of Quality in Educational Institutions) across all different types of independent work. Only $36.4 \%$ of academics have taken students' feedback on workload into consideration when planning the workload for their courses. It was also found that $92 \%$ of students were not informed about the number of hours planned for independent work at the beginning of the course. In addition, $88 \%$ of students were not asked to express their feedback about workload. These findings indicate that there are no unified regulations among academics to the estimation of student workload. It is also made clear that the process of estimating student workload in Credit Hour System at Alexandria University is staff-centred
\end{abstract}

* Saeed Alshamy (saeed.alshamy@edu.alexu.edu.eg; saeed.alshamy@gmail.com), PhD in Education, is an assistant professor at Foundations of Education Department, Faculty of Education, Alexandria University, Egypt. More details are available at the end of this article. 
rather than student-oriented as the majority of academics follow traditional methodologies in the estimation of student workload. It is also enunciated clearly that there is marginal coordination between academics teaching in the same programme. It can be concluded that student voice about their workload is not adequately considered as their feedback is not taken into consideration, which can be interpreted in light of the absence of a "paradigm shift" from staff-centred to student oriented approaches to the estimation of student workload.

Keywords: Alexandria University; Tuning Africa Project II; Credit Hour System; Student workload; Competence-based learning; higher education.

\section{Introduction}

The recognition that higher education is a major driver of economic competitiveness in the global knowledge economy has made its quality ever more important, and hence one of the most crucial challenges facing countries has been how to manage a rapidly growing higher education sector while maintaining its quality. In that respect, several countries all over the world have been trying to set credit systems and qualification frameworks which demonstrate students' academic progress or completion of their courses and degrees, facilitate student and staff mobility; improve transparency and mutual recognition between higher education institutions nationally and internationally.

The Course-Credit System or Credit Hour System, for instance, provided an effective means of measuring academic work for more than a century in the United States of America and has been successful in providing accountability, mobility, and regulation for a mass academic system. ${ }^{1}$ In Europe, the European Credit Transfer System (ECTS) has been introduced in 1989 to promote comparability and compatibility, students and staff mobility, transparency and fairness to students and integrate European Higher Education Area (EHEA). It represents an approach to European learning and teaching which places the student at the centre of the educational process. ${ }^{2}$ However, this is not the case for African higher

${ }^{1}$ Philip Altbach, "Measuring academic progress: the course-credit system in American higher education," Higher Education Policy 14 (2001): 37-44; Ayaka Noda, "How Do Credit Hours Assure the Quality of Higher Education? Time-Based vs. Competency-Based Debate" (CEAFJP Discussion Paper Series 16-05, Centre d'Etudes Avancées Franco-Japonais de Paris, 2016).

2 “ECTS User's Guide,” accessed September 10, 2016, https://ec.europa.eu/education/ sites/education/files/ects-users-guide_en.pdf. 
education as there is no unified academic credit system shared by all African countries.

\section{Context and rationale for the study}

The study aims at investigating the perceptions of both academics and students on student workload in Credit Hour System at Faculty of Education - Alexandria University. The rationale for conducting this study is that there is no academic credit system shared by all African countries. Moreover, many higher education institutions in the African continent are still rather unfamiliar with a credit system purported to support curricular change and lead the shift towards a student-centred and competence-based higher education. ${ }^{3}$

During the second general meeting of Tuning Africa Project - II, a method was defined for estimating student workload using a questionnaire survey. There has been a call to develop a country report on Credit System in each of the African countries. ${ }^{4}$ In response to this call, Alexandria University - as a Tuning member - has started surveying both academics and students on student workload in the programme "Professional Diploma in Education entitled: Quality of Educational Systems and Academic Accreditation" at Faculty of Education. This programme is being revised to be compatible with Tuning methodology and competence-based learning. The survey of student workload has been administered to academics and students in that programme.

Credit Hour System has been in place in the Faculty of Education, Alexandria University, since 2009. It is implemented at the graduate level whereas the undergraduate level still follows the traditional system (One year composed of two semesters, each semester includes different courses rather than credits). The implementation of the Credit Hour System in Egypt varies from one university to another and at the same university from one faculty to another.

\footnotetext{
3 "What is Tuning Africa?," Tuning Africa - II, accessed March 20, 2016, http:// tuningafrica.org/en/what-is-tuning-africa.

4 "Tuning Africa II. Second general meeting. Addis Ababa, 29 February - 2 March," accessed March 20, 2016, http://tuningafrica.org/upload/evento/editor/doc/2/booklet_teachereducation_english.pdf.

${ }^{5}$ Supreme Council of Universities - Sector Committee for Education, Student Guide for postgraduate studies according to Credit Hour System (Alexandria: El Gomhoreya Press, 2010).
} 
However, it might be noted that there is a misnaming of what is called Credit Hour System. Actually, what is applied is a teaching hour system focusing on Contact Hours ${ }^{6}$ and has nothing to do with the real hours of independent work needed by a student to pass a course or module and be able to localize and process the information received, internalize, reflect and construct their own meanings to transform this information into knowledge and mobilize and contextualize this knowledge in simulated situations or practices that permit the consolidation of learning. ${ }^{7}$ Thus, student workload is not currently taken into account at Faculty of Education - Alexandria University.

There are three different kinds of institutions of Teacher Education in Egypt: Faculties of Education (29), Faculties of Kindergarten (9) and Faculties of Specific Education (17). Credit Hour System is not adopted nationwide as some faculties adopt it whereas others follow the traditional system, the course based system. Those faculties adopting Credit Hour System implement it at graduate level whereas undergraduate level programmes adopt the traditional system. Moreover, there are variations between those different kinds of faculties in adopting Credit Hour System, as mentioned above. Accordingly, an effort has been launched by Sector Committee for Education ${ }^{8}$ which has been approved by Supreme Council of Universities (SCU), ${ }^{9}$ entitled: "Student Guide for post graduate studies according to Credit Hour System" to minimize such variations. ${ }^{10}$

In general, duration of an academic hour at Alexandria University, for all programmes at different departments, is equivalent to 60 minutes. 1 Credit Hour is a measuring unit for deciding the weight of each course in the semester, where it equals:

- 1 hour of theoretical lecture per week

- or 2 hours of practical work or laboratory work per week

- or 4 hours of field work per week across the whole semester

The number of Credit Hours per year differs from one programme to another. As far as the programme of "Professional Diploma in Education

${ }^{6}$ Contact Hours represent the amount of time spent on face to face teaching in a particular unit/course/module (including lectures, seminars, clinical practices, supervised labs, project work and field work) as well as on-line interaction in the framework of a learning module and personal counseling.

7 "What is Tuning Africa?," Tuning Africa - II.

${ }^{8}$ The Education Sector Committee is the entity responsible for discussing all issues related to Faculties of Education and giving its recommendations to SCU.

9 The entity responsible for regulation of higher education at the national level.

${ }^{10}$ Supreme Council of Universities, Student Guide for postgraduate studies. 
entitled: Quality of Educational Systems and Academic Accreditation" is concerned, number of Credit Hours per year is 22 (22 contact hours: nine compulsory courses (two hours each) and four elective ones, two of which can be chosen and studied across two semesters). Since the courses are split into two semesters, the number of contact hours per week in each of the two semesters is respectively 12 and 10 as indicated in Table 1 . According to the regulations of Credit Hour System at Alexandria University, the semester is composed of 16 weeks: 14 weeks of contact between academics and students and two weeks for oral and written exams. ${ }^{11}$

\section{Table 1}

Compulsory and Elective Courses in "Professional Diploma in Education entitled: Quality of Educational Systems and Academic Accreditation"

\begin{tabular}{|c|c|c|}
\hline \multicolumn{3}{|c|}{ First Semester: Fall } \\
\hline Code & Course title & $\begin{array}{c}\text { Credit } \\
\text { Hour }\end{array}$ \\
\hline \multicolumn{3}{|c|}{ Compulsory courses } \\
\hline 1. & Conceptual Introduction to Quality & 2 \\
\hline 2. & Philosophy of Academic Accreditation & 2 \\
\hline 4. & Educational Research & 2 \\
\hline 6. & Professional Development and Educational Quality & 2 \\
\hline 8. & Preparing Students for Knowledge Society & 2 \\
\hline \multicolumn{3}{|c|}{ Elective Courses } \\
\hline 10. & Readings in Quality Assurance and Academic Accreditation & 2 \\
\hline 12. & Standards of Implementing Quality Management in Education & 2 \\
\hline \multicolumn{3}{|c|}{ Second Semester: Spring } \\
\hline Code & Course title & $\begin{array}{l}\text { Credit } \\
\text { Hour }\end{array}$ \\
\hline \multicolumn{3}{|c|}{ Compulsory courses } \\
\hline 3. & Quality Assurance Management in Education & 2 \\
\hline 5. & Assessment of Quality in Educational Institutions & 2 \\
\hline
\end{tabular}

11 Ibid., 49. 


\begin{tabular}{|c|l|c|}
\hline \multicolumn{2}{|c|}{ Second Semester: Spring } \\
\hline Code & \multicolumn{1}{|c|}{ Course title } & $\begin{array}{c}\text { Credit } \\
\text { Hour }\end{array}$ \\
\hline 7. & Approaches to School Enhancement & 2 \\
\hline 9. & Preparing Educational Institutions for Knowledge Society & 2 \\
\hline \multicolumn{2}{|c|}{ Elective Courses } & 2 \\
\hline 11. & World Trends in Quality Assurance Systems & 2 \\
\hline 13. & Social and Cultural Aspects of Quality Assurance & \\
\hline
\end{tabular}

Having stated that the programme of "Professional Diploma in Education entitled: Quality of Educational Systems and Academic Accreditation" is composed of 22 Credit Hours per year split into two semesters, 12 and 10 respectively, it should be noted that courses from N. 1 to N. 9 are compulsory courses whereas courses from N. 10 to N. 13 are elective ones as indicated in Table 1.

Since there are four elective courses, two of which can be chosen and studied across two semesters, it was expected that there would be diversity among students in choosing elective courses but this was not the case. Due to the fact that the number of students in that Diploma is limited (15 students) and that they are graduated almost from the same programme, they tend to agree upon choosing a certain elective course in each semester. This is a common phenomenon in most postgraduate programmes at Faculty of Education, where the number of students is limited. In the academic year where this investigation was conducted, all students agreed upon choosing elective course No. 10 "Readings in Quality Assurance and Academic Accreditation" in the first semester and elective course No.11 "World Trends in Quality Assurance Systems" in the second semester. Moreover, according to the postgraduate bylaw at Faculty of Education, each elective course should be assigned to one academic as there are not enough academics to assign more than one for each elective course due to academics' heavy workload.

The number of Credit Hours used for different levels (Diploma, Master, Ph.D.) is variable. As far as Faculty of Education - Alexandria University is concerned; there are five different graduate programmes: ${ }^{12}$

12 Ibid., 25-37. 
- General Diploma in Education: one-year programme for noneeducation graduates - graduates who have qualifications other than Education Studies - and would like to work as teachers to be equivalent to education graduates. Graduates of this programme are awarded the degree of "General Diploma in Education". They are eligible to teach in both middle and secondary schools. General Diploma is 30 Credit Hours (30 contact hours: 28 compulsory and 2 elective).

- Professional Diploma in Education: one-year programme for education graduates and holders of the degree of General Diploma in Education, where students start to specialize in a chosen discipline. It is 22 Credit Hours (22 contact hours: 18 compulsory and 4 elective).

- Special Diploma in Education: one-year programme for holders of Professional Diploma in Education to pursue advanced levels in the chosen the specialization. It is 24 Credit Hours (24 contact hours: 18 compulsory and 6 elective).

- MA in Education: One-year programme composed of 32 Credit Hours (32 contact hours divided into 24 hours for courses and 8 hours for thesis writing upon the completion of the required courses). As far as courses are concerned, they differ from one department to another and from one programme to another. In general, two courses are elective whereas the rest is compulsory.

- Ph.D. in Education: One-year programme composed of 42 Credit Hours (42 contact hours divided into 21 hours for courses and 21 hours for thesis writing upon the completion of the required courses). The 21 contact hours cover a group of courses. The number of courses differs from one department to another and from one programme to another. In general, two courses are elective whereas the rest is compulsory.

The way Credit Hours are allocated to a degree programme is usually regulated by the Supreme Council of Universities (SCU) for Education studies upon recommendations of the Education Sector Committee. ${ }^{13}$ It is worth noting that this stage is followed by consultations at departmental levels at each Faculty to decide the allocation of credits and courses.

13 "Responsibilities of the SCU,” accessed March 1, 2016, http://portal.scu.eun.eg/ Responsiblities.html. 
At the national level, Alexandria University wishes to have a unified Credit Hour System which could facilitate student mobility from a university to another in Egypt. At the continental level, Alexandria University aims to have a Credit System which is comparable to other African universities to facilitate harmonization process and student mobility within the continent. This issue is of paramount importance when bearing in mind that Cairo University has a branch in Sudan whereas Alexandria University has a branch in South Sudan ${ }^{14}$ and a branch under construction in Republic of Chad and is planning to have branches in other African countries. ${ }^{15}$

The main aim of this study, therefore, is to use the wider international experience of higher education reform, including Tuning Africa Project - II, to propose implications for policy and practice on how the real hours of work needed by a student to achieve the learning outcomes specified in the curriculum and pass a course or module are adequately estimated and to contribute to the definition of the basis of a Credit System for Africa. This aim can be achieved through addressing the following research questions:

1. What are the perceptions of academics on student workload in Credit Hour System in the revised programme at Alexandria University?

2. What are the perceptions of students on their workload in Credit Hour System in the revised programme at Alexandria University?

3. What are the foreseeable implications - according to study findings for policy and practice?

\section{Student Workload in Higher Education programmes: the Tuning Approach}

While some less widely used credit systems are based on various criteria such as the importance of a subject or the number of contact hours in a course; the European Credit Transfer and Accumulation System (ECTS $)^{16}$ - the most commonly used basis for measuring student workload

\footnotetext{
14 “Alexandria University's Branch in Sudan,” accessed June 1, 2016, http://www.portal. alexu.edu.eg/index.php/en/about-au/branches/south-sudan-2.

15 “Alexandria University's Branch in Republic of Chad," accessed June 1, 2016, http:// www.portal.alexu.edu.eg/index.php/en/about-au/branches/chad.

16 "ECTS User's Guide."
} 
in European higher education - describe only student workload in terms of time employed to complete a course or a course unit. ECTS was instituted in 1989, within the Erasmus programme, as a way of transferring credits that students earned during their studies abroad into credits that counted towards their degree, on their return to studying in their home institution. It represents an approach to European learning and teaching which places the student at the centre of the educational process. ECTS is a central tool in the Bologna Process for promoting comparability and compatibility, student and staff mobility, transparency and fairness to students in European Higher Education. ${ }^{17}$

Student workload in ECTS consists of the time required to complete all planned learning activities such as attending lectures, seminars, independent and private study, placements, preparation of projects, examinations, and so forth. It was agreed that one regular year of student work is equivalent to 60 ECTS credits, in any degree course at any level (either undergraduate or postgraduate). On the average, according to several surveys, this corresponds to 1500 hours of annual student's workload, i.e. 1 ECTS credit is equal - again on the average - to 25 hours of student workload. Credits are allocated to all educational components of a study programme (such as modules, course units, etc.) and reflect the quantity of work each component requires to achieve its specific objectives or learning outcomes in relation to the total quantity of work necessary to complete a full year of study successfully. Approaches to teaching, learning and assessment have an impact on the workload required to achieve the desired learning outcomes and, consequently, on credit allocation. ${ }^{18}$

The Tuning Approach for determining student workload in Higher Education programmes consists of four steps as shown in Figure 1 (see next page).$^{19}$

First, introducing modules/course units. A choice must be made between the use of a modularized or a non-modularized system. In a non-modularized system each course unit can have a different number of credits although the total credits for each academic year will still be 60 credits. In a modularized system, the course units/modules have a fixed number of credits, 5 credits for

17 Robert Wagenaar, "Educational structures, learning outcomes, workload and the calculation of ECTS credits," in Tuning Educational Structures in Europe. Universities' contribution to the Bologna Process. An introduction, $2^{\text {nd }}$ ed., ed. Julia González and Robert Wagenaar (Bilbao: University of Deusto Press, 2008).

${ }_{18}$ Julia González and Robert Wagenaar, eds., Tuning Educational Structures in Europe II. Universities' Contribution to the Bologna Process (Bilbao: University of Deusto Press, 2005), 158-160.

${ }^{19}$ González and Wagenaar, eds., Tuning Educational Structures in Europe II, 163-166. 
example, or a multiple of this number. The use of a modularized system in an institution facilitates the use of the same modules by students enrolled in different programmes.

An approach

IV. Adjustment of
the unit either with
regard to the
number of credits
allocated or the
educational
activities

I. Module

(number of credits / student hours)

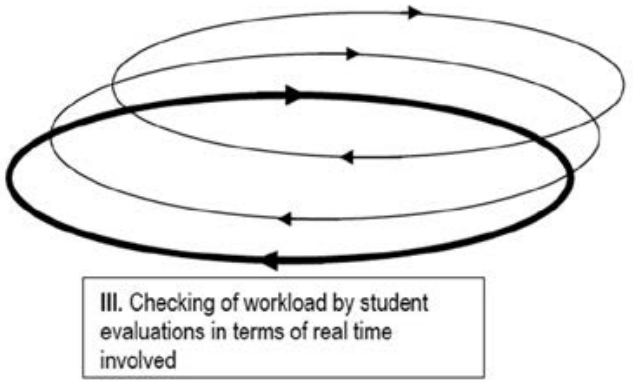

II. Planning educational activities / determining student time involved

Figure 1

Tuning Approach for determining student workload in Higher Education Programmes

Second, estimating student workload. The workload of a module/course unit is based on the total amount of learning activities a student is expected to complete in order to achieve the foreseen learning outcomes. It is measured in time (in work hours); for example, a module of 5 credits allows for around 125-150 hours of work of a typical student. Educational activities can be defined by considering several aspects such as: modes of instruction; types of learning activities; and types of assessment.

Third, checking the estimated workload through student evaluations. There are different methods to check whether the estimated student workload is correct. The most common method is the use of questionnaires to be completed by students, either during the learning process or after the completion of the course.

Fourth, Adjustment of workload and/or educational activities. An adjustment of workload and/or activities is required when the monitoring process reveals that the estimated student workload does not correspond to the actual workload.

It is worth noting that the process of planning educational activities/ estimating student workload; checking the estimated workload through student evaluations; and adjustment of workload and/or educational activities 
is a continuous process, which keeps students at the centre of the educational process.

\section{Research design and procedures}

The study is located within a broadly interpretive methodology, using a case study approach with questionnaires on student workload administered to academics and students at Faculty of Education - Alexandria University as the main method of data collection, utilizing qualitative and quantitative data and approaches in all its components. It is worth noting that the study has used the same questionnaires for student workload, which were developed in Tuning Africa Project - II.

The interpretive methodology is viewed as suitable as it is believed that there are multiple interpretations of, and perspectives on, single events and situations (student workload) and that reality is multilayered and complex. An interpretive approach is primarily concerned with human understanding, interpretation and intersubjectivity, in essence lived experience or lived truth in its natural social context from the standpoint of individuals who are part of the ongoing action being investigated.$^{20}$ However, precautions have been taken to overcome the risk of bias and subjectivity. ${ }^{21}$ These include data triangulation (through gathering multiple viewpoints: academics and students) and cross-referencing cases within the sample together with other precautions to enhance validity and reliability and ensure rigour of the findings that will be discussed later in the study.

This study is a detailed investigation of the perceptions of academics and students of Faculty of Education, Alexandria University - as a case study on student workload. Questionnaires were administered to academics and students with a view to an analysis of the context and processes involved in the phenomenon under study. The selected cases have enabled the researcher to develop detailed knowledge of the experience of participants on student workload at Alexandria University and an examination of the strengths and weaknesses of existing system, leading to an identification of implications for policy and practice for enhancing the quality of Teacher Education Programmes in Egyptian higher education.

${ }^{20}$ Noella Mackenzie and Sally Knipe, "Research Dilemmas: Paradigms, Methods and Methodology," Issues In Educational Research 16, no. 2 (2006): 193-205.

${ }^{21}$ Norman K. Denzin and Yvonna S. Lincoln, Handbook of Qualitative Research (London: Sage, 2002). 
A case study approach is viewed as suitable as case studies examine relationships between cause and effect but do not claim to establish a direct causal link. The strength of a case study is that it enables researchers to observe effects in real contexts, recognizing that context is a powerful determinant of both causes and effects. Another strength of the approach is that it provides fine-grain details $\mathrm{s}^{22}$ as means for seeing situations through the eyes of participants. They are widely used in organizational studies in the social sciences..$^{23}$ Lastly, the multiplicity of the variables and sources of evidence that characterize a case study inquiry are a holistic approach which investigates the case as a whole, recognizing its real-life context, rather than dealing with isolated factors. ${ }^{24}$

A mixed sample of academics and students was approached for two main reasons. Firstly, to avoid a methodological problem concerning the possibility of academics having an interest in creating a successful image of the programmes provided at their faculties to show a good impression of their own effort. ${ }^{25}$ Secondly, having a mixed sample allows for triangulating the data through comparing the perceptions of participants on issues under investigation.

The total sample of this investigation is 26 split into 11 academics (one academic per course) and 15 students who have been investigated 11 times for their perceptions on student workload across 11 courses of the Diploma (15 students surveyed 11 times once for each course of the Diploma under investigation, that is, 165 surveys/cases: 11 surveys for each student).

The survey process has been conducted in two stages. The first stage took place after the final assessment of the first semester was finished and the results were announced; both academics and students were asked about their perceptions on student workload across the six courses of the first semester. The second stage took place after the final assessment of the second semester was finished and the results were announced; both academics and students

${ }^{22}$ Louis Cohen et al., Research Methods in Education, $6^{\text {th }}$ ed. (London: Routledge, 2007).

${ }^{23}$ Christine Benedichte Meyer, "A Case in Case Study Methodology," Field Methods 13, no. 4 (2001): 329-325.

${ }^{24}$ Robert K. Yin, Case Study Research: Design and Methods, 3rd ed. (London: SAGE, 2003).

${ }^{25}$ Bjrn Stensaker, "Trance, Transparency and Transformation: the impact of external quality monitoring on higher education," Quality in Higher Education 9, no. 2 (2003): 151159; Viktoria Kis, "Quality Assurance in Tertiary Education: Current Practices in OECD Countries and a Literature Review on Potential Effects" (paper presented as a contribution to the OECD Thematic Review of Tertiary Education, 2005), accessed July, 1 2012, http://www. oecd.org/dataoecd/55/30/38006910.pdf. 
were asked about their perceptions on student workload across the five courses of the second semester. Having given these details, it is clear that the time at which the survey was conducted is chosen consistently with what is asked for in the questionnaires, especially question 11-f (the estimated number of hours needed for preparing for summative assessment), which is feasible for all participants. Before filling out the questionnaire, a brief background was given to academics and students about the aim of the study and they were well-informed that the collected data would be totally anonymous and confidential. All questions of the survey were answered by all respondents.

\section{Findings and discussion}

Overall, it is striking to note that students' estimation of the number of hours needed to complete the independent work across all courses during the semester were much higher than that of academics except for fieldwork (site visits) where academics' estimations came higher than those of students. Table 2 and Figure 2 show the differences between the perceptions of both students and academics concerning the estimation of student workload across different courses of the Professional Diploma in Education.

Table 2

Students and Academics' perceptions on the estimation of student workload

\begin{tabular}{|c|c|c|c|c|c|c|c|c|c|c|c|c|c|}
\hline \multirow[b]{2}{*}{ No. } & \multirow[b]{2}{*}{ Survey Questions } & \multicolumn{2}{|c|}{ Count } & \multicolumn{2}{|c|}{ Mean } & \multicolumn{2}{|c|}{ Median } & \multicolumn{2}{|c|}{$\begin{array}{c}\text { Percentile } \\
25\end{array}$} & \multicolumn{2}{|c|}{$\begin{array}{c}\text { Percentile } \\
75\end{array}$} & \multicolumn{2}{|c|}{$\begin{array}{l}\text { Standard } \\
\text { Deviation }\end{array}$} \\
\hline & & 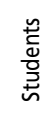 & 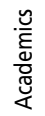 & 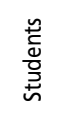 & 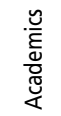 & 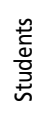 & 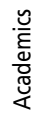 & 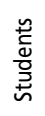 & 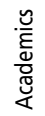 & 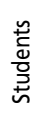 & 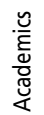 & 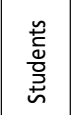 & 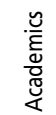 \\
\hline $10-$ & $\begin{array}{l}\text { How many } \\
\text { CONTACT } \\
\text { HOURS in total } \\
\text { are there in } \\
\text { your unit/course/ } \\
\text { module during } \\
\text { the SEMESTER? }\end{array}$ & 165 & 11 & 28.0 & 28.0 & 28 & 28 & 28 & 28 & 28 & 28 & .00 & .00 \\
\hline $11-a$ & $\begin{array}{l}\text { Reading } \\
\text { materials } \\
\text { (including } \\
\text { internet search) }\end{array}$ & 165 & 11 & 19.0 & 10.3 & 15 & 10 & 10 & 7 & 28 & 14 & 13.34 & 3.98 \\
\hline
\end{tabular}




\begin{tabular}{|c|c|c|c|c|c|c|c|c|c|c|c|c|c|}
\hline \multirow[b]{2}{*}{ No. } & \multirow[b]{2}{*}{ Survey Questions } & \multicolumn{2}{|c|}{ Count } & \multicolumn{2}{|c|}{ Mean } & \multicolumn{2}{|c|}{ Median } & \multicolumn{2}{|c|}{$\begin{array}{l}\text { Percentile } \\
\quad 25\end{array}$} & \multicolumn{2}{|c|}{$\begin{array}{l}\text { Percentile } \\
\quad 75\end{array}$} & \multicolumn{2}{|c|}{$\begin{array}{l}\text { Standard } \\
\text { Deviation }\end{array}$} \\
\hline & & 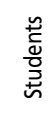 & 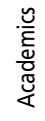 & 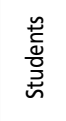 & 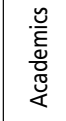 & $\begin{array}{l}\stackrel{0}{c} \\
\text { 竞 } \\
\text { 离 }\end{array}$ & 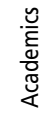 & 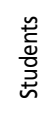 & 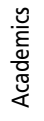 & $\begin{array}{l}\stackrel{n}{0} \\
\frac{0}{0} \\
\text { 总 }\end{array}$ & 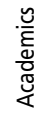 & $\begin{array}{l}\stackrel{n}{0} \\
\frac{0}{0} \\
\text { Dे }\end{array}$ & $\begin{array}{l}\frac{\tilde{y}}{\varepsilon} \\
\frac{\mathscr{d}}{\sigma} \\
\frac{\pi}{4}\end{array}$ \\
\hline $11-b$ & $\begin{array}{l}\text { Fieldwork (site } \\
\text { visits, etc.) }\end{array}$ & 165 & 11 & .2 & 1.8 & 0 & 0 & 0 & 0 & 0 & 0 & 1.72 & 6.03 \\
\hline $11-c$ & $\begin{array}{l}\text { Laboratory work } \\
\text { (not counting in } \\
\text { contact hours) }\end{array}$ & 165 & 11 & .0 & .0 & 0 & 0 & 0 & 0 & 0 & 0 & .00 & .00 \\
\hline $11-d$ & $\begin{array}{l}\text { Preparation of } \\
\text { assignments }\end{array}$ & 165 & 11 & 17.9 & 10.0 & 15 & 14 & 10 & 6 & 28 & 14 & 13.02 & 5.14 \\
\hline $11-\mathrm{e}$ & $\begin{array}{l}\text { Preparation and } \\
\text { follow- up work } \\
\text { for scheduled }\end{array}$ & 165 & 11 & 14.6 & 9.7 & 14 & 14 & 14 & 5 & 18 & 14 & 8.93 & 5.24 \\
\hline $11-f$ & $\begin{array}{l}\text { Preparation for } \\
\text { assessment, final } \\
\text { examinations, } \\
\text { tests, etc. } \\
\text { (summative } \\
\text { assessment) }\end{array}$ & 165 & 11 & 38.1 & 23.6 & 35 & 28 & 30 & 12 & 42 & 30 & 16.64 & 8.43 \\
\hline $11-g$ & Other & 165 & 11 & .1 & .0 & 0 & 0 & 0 & 0 & 0 & 0 & .66 & .00 \\
\hline 12 & $\begin{array}{l}\text { How many } \\
\text { hours does } \\
\text { an AVERAGE } \\
\text { student need to } \\
\text { complete all the } \\
\text { requirements in } \\
\text { this SEMESTER }\end{array}$ & 165 & 11 & 118 & 83 & 116 & 77 & 88 & 58 & 139 & 100 & 37 & 22.10 \\
\hline 13 & $\begin{array}{l}\text { How many } \\
\text { hours does } \\
\text { an AVERAGE } \\
\text { student need to } \\
\text { complete all the } \\
\text { requirements } \\
\text { per WEEK }\end{array}$ & 165 & 11 & 8 & 6 & 8 & 5 & 6 & 4 & 10 & 7 & 3 & 1.49 \\
\hline \multicolumn{2}{|c|}{$\begin{array}{l}\text { TOTAL INDEPENDENT } \\
\text { WORKLOAD per Course }\end{array}$} & & & 89.9 & 55.45 & \multirow{2}{*}{\multicolumn{8}{|c|}{ RATIO Academics over Students $=61.69 \%$}} \\
\hline $\begin{array}{l}\text { TOTA } \\
\text { WORI }\end{array}$ & $\begin{array}{l}\text { L INDEPENDENT } \\
\text { KLOAD per year }\end{array}$ & & & 988.8 & 610 & & & & & & & & \\
\hline
\end{tabular}




\section{Students}

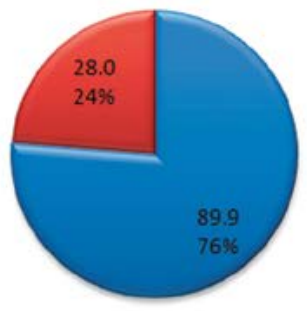

Independent Work $\quad$ Contact Hours
Academics

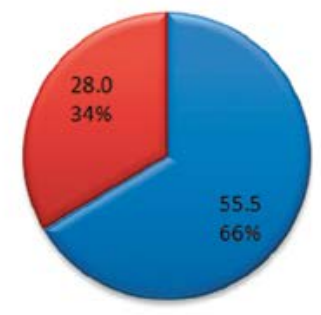

Independent Work $\mathbf{\theta}$ Contact Hours

\section{Figure 2}

Students and Academics' perceptions on the estimation of student workload

It is clear from Table 2 and Figure 2 that the total number of Contact Hours of a given course unit is the same ( 28 hours) for both academics and students as according to the regulations of Credit Hour System at Alexandria University concerning the Diploma under investigation, the semester is composed of 16 weeks: 14 weeks of contact between academics and students - two hours each - and two weeks for oral and written exams. It is also clear that both academics and students gave no hours for laboratory work as the nature of this Professional Diploma in Education does not require any laboratory work. The questionnaire is consisted of 15 points/questions and points 1 to 9 have been informed by the university so participants are invited to respond to the items 10-15 (See Annex I: Questionnaire for Academics; and Annex II: Questionnaire for Students).

It is prominent to note that students' estimation of the number of hours needed for "reading materials (including internet search) and preparation of assignments" was almost double the number of hours estimated by academics.

It is also clear that students' estimation of the number of hours needed for "preparation and follow-up work for scheduled classes and preparation for assessment, final examinations, tests, etc." was almost one times and a half the number of hours estimated by academics.

On the other hand, academics' estimation of the number of hours needed for "fieldwork (site visits)" was much higher than students' estimation. When students were asked to add any other ways of learning they used that are not included in the survey, only 2 out of 165 cases mentioned site visits to both accredited schools and none-accredited schools to meet teachers, 
head teachers and students. They also mentioned site visits to the National Authority of Quality Assurance and Accreditation in Education (NAQAAE) to meet people in charge of applying quality assurance systems in education in Egypt.

The above results in Table 2 indicate that there is a significant gap between the perceptions of academics and students on student workload in Credit Hour System at Alexandria University, where students' estimation of the number of hours needed to complete independent work were much higher (89.9 hours per course) than those of academics (55.45 hours per course). The figures in Table 2 also indicate that the independent workload as estimated by academics is $62 \%$ of students' estimation.

A significant gap between the perceptions of academics and students was also found in their responses to Questions N. 14 and N. 15 of the survey as shown in Table 3 and Figure 3. Question N. 14 asked academics if they have estimated the hours students will have to spend on independent work when planning their courses and asked students, on the other hand, if they were informed about the number of hours planned for independent work at the beginning of the course. Question N. 15 asked academics if they took students' feedback on workload into consideration when planning the workload for their courses and asked students, on the other hand, if they were given the opportunity to provide feedback about the workload in the course.

It has been observed that $82 \%$ of academics have estimated the hours students will have to spend on independent work when planning their courses. However, only $36.4 \%$ of those academics have taken students' feedback on workload into consideration when planning the workload for their courses whereas the other $63.6 \%$ never took students' feedback on workload into consideration as shown in Table 3 and Figure 3.

On the other hand, it was found that $92 \%$ of students were not informed about the number of hours planned for independent work at the beginning of the course. In addition, $88 \%$ of students were not given the opportunity to express their feedback about the workload in the courses of the diploma.

Table 3

Responses of Academics and Students to Questions N. 14 and N. 15

\begin{tabular}{|l|c|c|c|c|}
\cline { 2 - 5 } \multicolumn{1}{c|}{} & \multicolumn{2}{c|}{ Q.14 } & \multicolumn{2}{c|}{ Q.15 } \\
\hline \multirow{2}{*}{ Academics } & Yes & No & Yes & No \\
\cline { 2 - 5 } & $81.8 \%$ & $18.2 \%$ & $36.4 \%$ & $63.6 \%$ \\
\hline Students & $7.9 \%$ & $92.1 \%$ & $12.1 \%$ & $87.9 \%$ \\
\hline
\end{tabular}




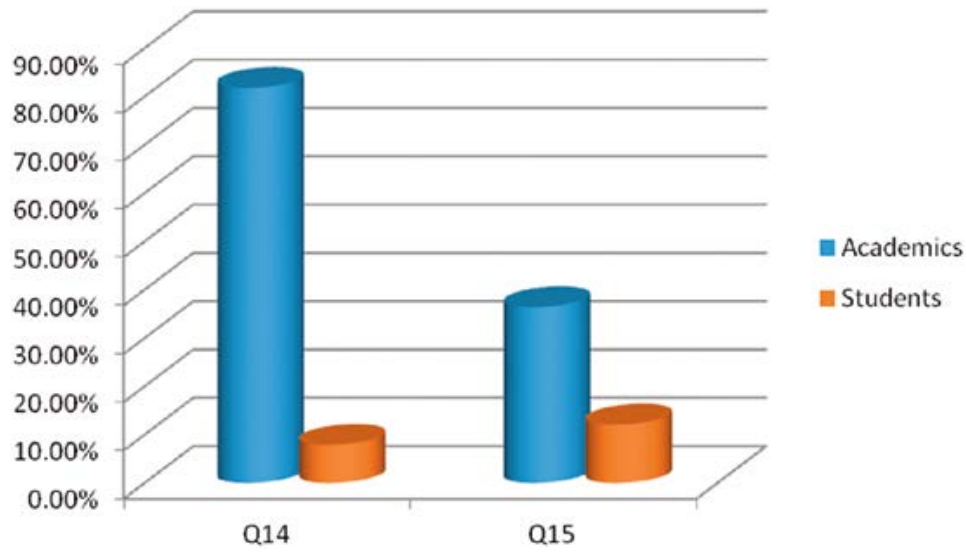

Figure 3

Responses of Academics and Students to Questions N. 14 and N. 15.

These findings indicate that there are no unified regulations among academics for the estimation/allocation of student workload. It is also made clear that the process of estimating student workload in Credit Hour System at Alexandria University is staff-centred rather than student oriented as the majority of academics follow traditional methodologies in their estimation of student workload. It can be concluded that student voice about their workload is not adequately considered as their feedback is not taken into consideration.

Concerning these findings, the Tuning approach for determining student workload in Higher Education programmes offers two forms that can be helpful in informing students about the number of hours planned for independent work at the beginning of the course, taking their feedback and making decisions on adjustment of the student workload accordingly. The first form is for academics to plan the educational module and estimate the student working hours involved. The second is for the student to indicate the actual amount of time spent on the module, thus providing an opportunity to check whether the estimated workload corresponds to reality. Students are given the form completed by the teacher where only the estimated workload is not shown. By using these forms both academics and students become aware of the learning outcomes, their relationship to the competences being developed and the average student time involved for each of the tasks. ${ }^{26}$

${ }^{26}$ González and Wagenaar, eds., Tuning Educational Structures in Europe II, 163-166. 
Having found a marked gap between the perceptions of academics and students concerning the estimation of student workload across different courses of the Professional Diploma in Education, different statistical tests have been used to decide the significance of such findings. Two tests of normality (Kolmogorov-Smirnov and Shapiro-Wilk) have been used to check the normality of the data and it was found that none of the variables distribute normally as the sample of this study is a paired/dependent sample (i.e. both academics and students were surveyed for their perceptions on student workload and the same students were asked the same questions on each course of the diploma). ${ }^{27}$ So, there was a need for non-parametric tests. Thus, two non-parametric tests (Wilcoxon Signed Ranks Test and Friedman Test) have been used. ${ }^{28}$ A significance level $\alpha \%=5 \%$ was adopted for all tests.

As stated before, the total number of the sample is 26 split into 11 academics (one academic for each course) and 15 students (each student surveyed 11 times on his/her perceptions on student workload across all courses of the Diploma, that is 165 questionnaires/cases). This explains why Wilcoxon and Friedman Tests were used. Wilcoxon Test was used as there are two related/dependent samples, academics and students. Friedman Test was used as the same 15 students have been asked 11 times (repeated measures/several related samples) about their perceptions on workload across all courses of the diploma.

Wilcoxon Signed Ranks Test has been used to check if there are significant differences (at a significance level $\alpha \%=5 \%$ ) between the perceptions of students and academics concerning the estimation of student workload across different courses of the Professional Diploma in Education as shown in Table 4 (see next page).

Wilcoxon Signed-Ranks Test also considers information about both the sign of the differences and the magnitude of the differences between pairs, academics and students. Here are the Null and Alternate Hypotheses which were tested using Wilcoxon Test.

$$
\begin{aligned}
& H_{\mathrm{o}}:(\text { Academics Perceptions }- \text { Students Perceptions })=0 \\
& H_{1}:(\text { Academics Perceptions }- \text { Students Perceptions }) \neq 0
\end{aligned}
$$

27 Gerard Dallal and Leland Wilkinson, "An analytic approximation to the distribution of Lilliefor's test statistic for normality," The American Statistician 40, no. 4 (1986): 294-296 (Correction: 41: 248).

${ }^{28}$ Sidney Siegel and John Castellan, Nonparametric statistics for the behavioral sciences (New York: McGraw-Hill, Inc., 1988). 


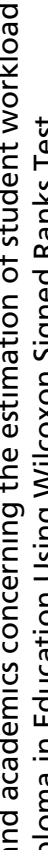

\begin{tabular}{|c|c|c|c|c|c|c|c|c|c|c|c|c|c|c|c|c|}
\hline 幽 = & $\begin{array}{l}\hat{0} \\
m \\
\tilde{p}\end{array}$ & $\overline{8}$ & $\begin{array}{l}\text { Oి } \\
6 \\
\text { r. }\end{array}$ & $\begin{array}{l}8 \\
0 \\
0\end{array}$ & 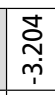 & $\overline{8}$ & 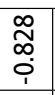 & $\stackrel{\infty}{q}$ & 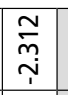 & $\bar{\delta}$ & $\begin{array}{l}8 \\
0 \\
0\end{array}$ & $\stackrel{\circ}{\circ}$ & 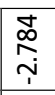 & $\stackrel{n}{\circ}$ & $\underset{m}{\stackrel{m}{m}}$ & \\
\hline 0 & 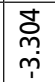 & $\overline{8}$ & ¿̊̊ & $\underset{-}{8}$ & 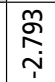 & Цّ & 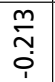 & $\underset{\infty}{\sim}$ & $\begin{array}{l}\underset{\sigma}{\sigma} \\
\stackrel{\Gamma}{r}\end{array}$ & $\bar{\varnothing}$ & $\begin{array}{l}8 \\
0 \\
0\end{array}$ & ه্ণ & $\stackrel{\bar{p}}{p}$ & ธิ & 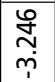 & \\
\hline$a$ & 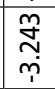 & $\overline{8}$ & ¿̊̊ & هి & 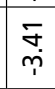 & $\overline{8}$ & 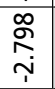 & ํㅗㅇ & 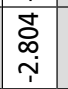 & 농 & $\begin{array}{l}\circ \\
0 \\
0\end{array}$ & 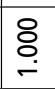 & & $\overline{8}$ & $\stackrel{\substack{n \\
m}}{m}$ & \\
\hline$\infty$ & $\begin{array}{l}\text { ț } \\
\text { o. } \\
\text { in }\end{array}$ & 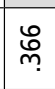 & ¿̊․ & 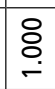 & 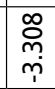 & $\bar{\varnothing}$ & 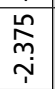 & $\stackrel{\infty}{\circ}$ & 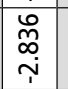 & $\stackrel{\text { L̊ }}{0}$ & $\begin{array}{l}8 \\
0 \\
0\end{array}$ & 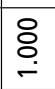 & $\begin{array}{l}\infty \\
\stackrel{0}{+} \\
m \\
i\end{array}$ & $\bar{\delta}$ & 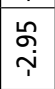 & \\
\hline - & $\begin{array}{l}\text { S } \\
\text { ì }\end{array}$ & $\stackrel{\infty}{\circ}$ & 㐫 & 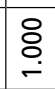 & 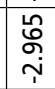 & \%̊. & 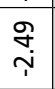 & $\stackrel{m}{\sigma}$ & 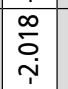 & J & $\begin{array}{l}8 \\
0 \\
0\end{array}$ & 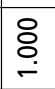 & $\begin{array}{l}\infty \\
\stackrel{0}{0} \\
\dot{\varphi} \\
\dot{p}\end{array}$ & ठิ & $\begin{array}{l}\text { Oे } \\
\dot{p}\end{array}$ & \\
\hline 6 & 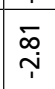 & ¿̊. & 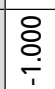 & $\overline{\bar{m}}$ & $\begin{array}{l}\stackrel{n}{\infty} \\
\stackrel{\sim}{\sim}\end{array}$ & ఫे & 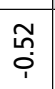 & ¿. & $\begin{array}{c}\bar{\infty} \\
0 \\
i\end{array}$ & 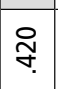 & $\begin{array}{l}8 \\
\stackrel{0}{0} \\
0\end{array}$ & 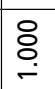 & 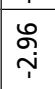 & $\check{o}_{0}$ & $\bar{r}$ & \\
\hline n & $\begin{array}{l}\hat{\infty} \\
\stackrel{p}{1}\end{array}$ & ঃ. & $\begin{array}{l}\text { o } \\
0 \\
0\end{array}$ & 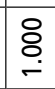 & 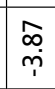 & চి & $\stackrel{\nabla}{r}$ & $\overline{8}$ & 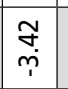 & $\bar{z}$ & $\begin{array}{l} \\
\\
0\end{array}$ & ه্ & $\stackrel{m}{m}$ & $\overline{8}$ & $\begin{array}{l}\bar{\gamma} \\
\dddot{y}\end{array}$ & \\
\hline$\sigma$ & 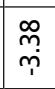 & $\overline{8}$ & ষ্ণ & $\underset{8}{8}$ & & ৪. & 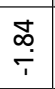 & И. & 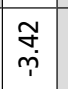 & $\overline{8}$ & $\begin{array}{l}8 \\
0 \\
0\end{array}$ & $\underset{-}{\stackrel{8}{\circ}}$ & $\underset{r}{\bar{f}}$ & $\overline{8}$ & $\underset{\sim}{\stackrel{\sim}{\sim}}$ & \\
\hline$m$ & $\underset{i}{\bar{i}}$ & $\stackrel{\text { Ln }}{\circ}$. & 㐫 & 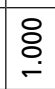 & & $\overline{8}$ & $\underset{\substack{m \\
\sim}}{m}$ & ญి & $\begin{array}{l}\tilde{\tilde{m}} \\
\stackrel{m}{r}\end{array}$ & $\overline{8}$ & $\begin{array}{l}8 \\
\stackrel{0}{0} \\
0\end{array}$ & $\underset{-}{\stackrel{8}{0}}$ & 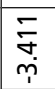 & $\overline{8}$ & 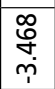 & \\
\hline 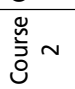 & $\bar{\sigma}$ & $\begin{array}{l}\text { 号 } \\
\text {. }\end{array}$ & ¿̊̀ & 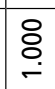 & চ্ণ & $\stackrel{g}{\dddot{m}}$ & 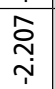 & 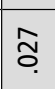 & 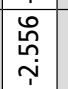 & $\bar{\sigma}$ & 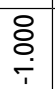 & $\bar{m}$ & $\begin{array}{l}\hat{\tilde{\hat{\sigma}}} \\
\stackrel{i}{\gamma}\end{array}$ & $\stackrel{\circ}{\circ}$ & \begin{tabular}{|c|}
$\stackrel{\sim}{\infty}$ \\
$\stackrel{\sim}{\sim}$
\end{tabular} & \\
\hline- & 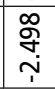 & $\tilde{\sigma}$ & 浐 & 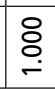 & & $\stackrel{0}{\rightleftharpoons}$ & 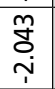 & $\bar{\delta}$ & 竞 & g̊ & 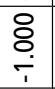 & $\frac{\bar{m}}{m}$ & 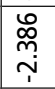 & $\bar{o}$ & 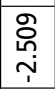 & \\
\hline 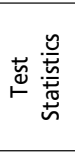 & $N$ & 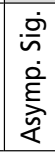 & $N$ & 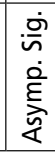 & $N$ & $\begin{array}{l}\bar{n} \\
\dot{\alpha} \\
\dot{\varepsilon}\end{array}$ & $N$ & $\begin{array}{l}\text { on } \\
\text { हू } \\
\text { हे }\end{array}$ & $N$ & 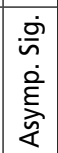 & $N$ & $\begin{array}{l}\text { 吕 } \\
\text { हे } \\
\text { हो }\end{array}$ & $N$ & 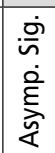 & $N$ & \\
\hline 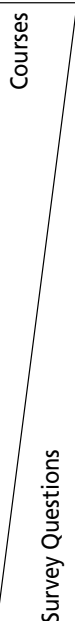 & 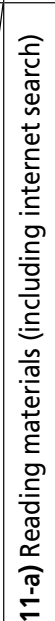 & & 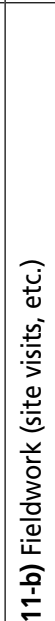 & & 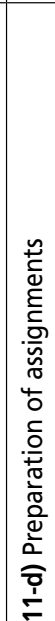 & & 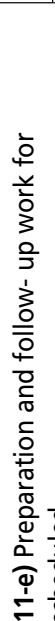 & & 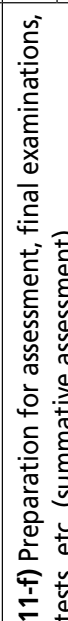 & & 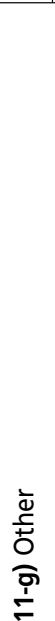 & & 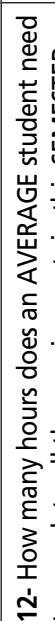 & & 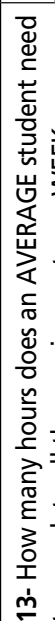 & 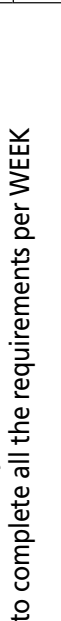 \\
\hline
\end{tabular}


The above highlighted cells in the table show significant differences between the perceptions of academics and students on student workload almost across all courses of the Professional Diploma in Education. The negative sign of " $Z$ " test shows that the estimation of student workload from the point of view of students were always higher than those of academics almost across all courses of the Professional Diploma in Education.

Concerning the number of hours an AVERAGE student needs to complete all the requirements during the SEMESTER and per week, it is clear that there are significant differences between the perceptions of academics and students across all courses of the Professional Diploma in Education.

Concerning reading materials, it is clear that there are significant differences between the perceptions of academics and students across all courses of the Professional Diploma in Education except courses (N. 2 "Philosophy of Academic Accreditation" \& N. 8 "Preparing Students for Knowledge Society") as shown in Table 1.

Concerning preparation of assignments, it is clear that there are significant differences between the perceptions of academics and students across all courses of the Professional Diploma in Education except courses (N. $1 \&$ N. 2).

Concerning preparation for assessment, final examination, tests, etc. (summative assessment) it is clear that there are significant differences between the perceptions of academics and students across all courses of the Professional Diploma in Education except courses (N. 1 \& N. 6).

Concerning preparation and follow-up work for scheduled classes, it is clear that there are significant differences between the perceptions of academics and students across all courses of the Professional Diploma in Education except courses (N. 4 \& N. $6 \&$ N. $10 \&$ N. 11 ).

Concerning fieldwork (site visits, etc.), it is clear that there are significant differences between the perceptions of academics and students at only one course (course N. 11). The data shows that this is the only course where the academic asked his students to make use of fieldwork (site visits).

These findings lead us to reject the Null Hypothesis and accept the Alternate Hypothesis as Wilcoxon Signed Ranks Test has proved that there are significant differences between the perceptions of students and academics concerning the estimation of student workload across different courses of the Professional Diploma in Education.

Friedman Test has been used to check if there are significant differences (at a significance level $\alpha \%=5 \%$ ) between the perceptions of students on the number of hours required for each different type of independent work across all courses of the Professional Diploma in Education as shown in Table 5. 


\begin{tabular}{|c|c|c|c|c|c|c|c|c|}
\hline \multirow{2}{*}{ 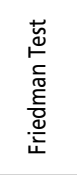 } & 产的 & & 우 & $\stackrel{1}{0}$ & 웅 & 웅 & 옹 & 导 \\
\hline & 它 & & 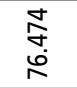 & $\begin{array}{l}\stackrel{m}{m} \\
\text { nn } \\
\end{array}$ & है & $\begin{array}{l}\text { ठ } \\
\text { ठ̊ }\end{array}$ & $\begin{array}{l}\stackrel{N}{N} \\
\stackrel{-}{=}\end{array}$ & $\begin{array}{l}8 \\
\circ\end{array}$ \\
\hline \multicolumn{2}{|c|}{ ьәбедәлҰ моу } & $\begin{array}{l}8 \\
\text { D } \\
\sim\end{array}$ & $\begin{array}{l}8 \\
\stackrel{0}{\circ}\end{array}$ & $\stackrel{\mathscr{N}}{\sim}$ & $\begin{array}{l}\infty \\
\stackrel{\infty}{=}\end{array}$ & $\begin{array}{l}\dot{U} \\
\dot{J}\end{array}$ & 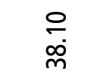 & ¿̊. \\
\hline $\begin{array}{c}\text { ll } \\
\text { נJə!qns }\end{array}$ & \multirow{11}{*}{ 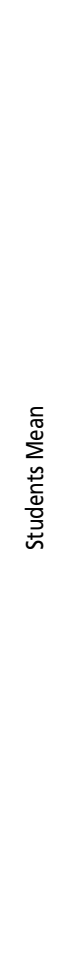 } & $\stackrel{\infty}{\sim}$ & $\begin{array}{l}\text { o } \\
\stackrel{m}{m}\end{array}$ & $\stackrel{\infty}{-}$ & $\begin{array}{l}\underset{m}{m} \\
\underset{\sim}{\infty}\end{array}$ & $\stackrel{\infty}{\underset{j}{ \pm}}$ & $\begin{array}{l}\infty \\
\infty \\
\text { Ln }\end{array}$ & 0 \\
\hline 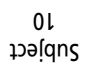 & & $\stackrel{\infty}{\sim}$ & $\begin{array}{l}\text { o } \\
\text { } \\
\text { in }\end{array}$ & 0 & $\stackrel{\infty}{\ddot{\sim}}$ & 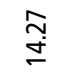 & 鬲 & 0 \\
\hline 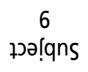 & & $\stackrel{\infty}{\sim}$ & $\begin{array}{l}\text { क } \\
\text { ம் }\end{array}$ & 0 & $\begin{array}{l}\stackrel{m}{m} \\
\text { ஸे }\end{array}$ & 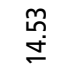 & $\begin{array}{l}m \\
m \\
q\end{array}$ & 0 \\
\hline $\begin{array}{c}8 \\
\text { رə!q̣ns }\end{array}$ & & $\stackrel{\infty}{\sim}$ & $\frac{m}{\grave{D}}$ & 0 & กิ & $\begin{array}{l}\text { ñ } \\
\text { ْ̊ }\end{array}$ & $\begin{array}{l}\text { f̊ } \\
\text { ơ }\end{array}$ & 0 \\
\hline$\stackrel{L}{L}$ & & $\stackrel{\infty}{\sim}$ & $\stackrel{f}{\stackrel{\sigma}{二}}$ & 0 & $\begin{array}{l}\text { Oे } \\
\stackrel{+}{\sim}\end{array}$ & ก̊n & స઼ & 0 \\
\hline 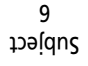 & & $\stackrel{\infty}{\sim}$ & $\stackrel{\varphi}{=}$ & ढ़ & $\stackrel{\text { I }}{\simeq}$ & $\begin{array}{l}\infty \\
\infty\end{array}$ & $\stackrel{\infty}{m}$ & 0 \\
\hline 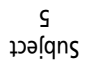 & & $\stackrel{\sim}{\sim}$ & 0 & 0 & 0 & †্ & $\stackrel{\infty}{\stackrel{m}{m}}$ & 0 \\
\hline 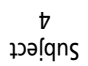 & & $\stackrel{\infty}{\sim}$ & $\stackrel{m}{m}$ & 0 & 0 & مુ & $\stackrel{\stackrel{9}{m}}{m}$ & 0 \\
\hline 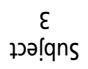 & & $\stackrel{\infty}{\sim}$ & $\begin{array}{l}\stackrel{\varphi}{\mathscr{L}} \\
\stackrel{\ln }{ }\end{array}$ & 0 & f & م. & $\begin{array}{l}\grave{\Xi} \\
\ddot{g}\end{array}$ & 0 \\
\hline 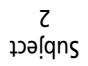 & & $\stackrel{\sim}{\sim}$ & $\begin{array}{l}\ddot{0} \\
\stackrel{-}{-}\end{array}$ & 0 & ¿্ं & $\begin{array}{l}m \\
\infty \\
\infty\end{array}$ & $\stackrel{f}{\text { f }}$ & t. \\
\hline 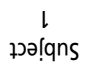 & & $\stackrel{\infty}{\sim}$ & f & 0 & $\begin{array}{l}\varphi \\
\stackrel{\infty}{-}\end{array}$ & f̊ & 字 & ப் \\
\hline 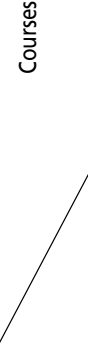 & 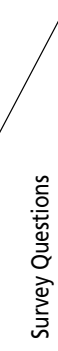 & 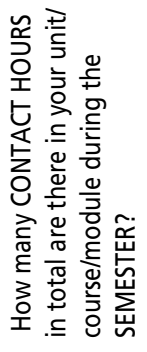 & 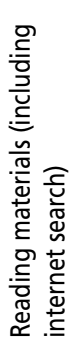 & 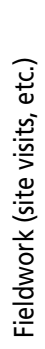 & 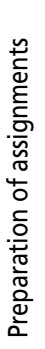 & 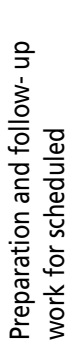 & 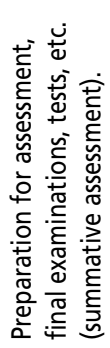 & $\frac{\grave{d}}{\stackrel{ᄒ}{\sigma}}$ \\
\hline & & 으 & $\stackrel{5}{\stackrel{5}{\leftarrow}}$ & $\stackrel{0}{\stackrel{1}{亡}}$ & $\stackrel{i}{\stackrel{1}{\prime}}$ & $\stackrel{\Phi}{\stackrel{1}{\leftarrow}}$ & $\stackrel{+}{=}$ & $\stackrel{9}{1}$ \\
\hline
\end{tabular}




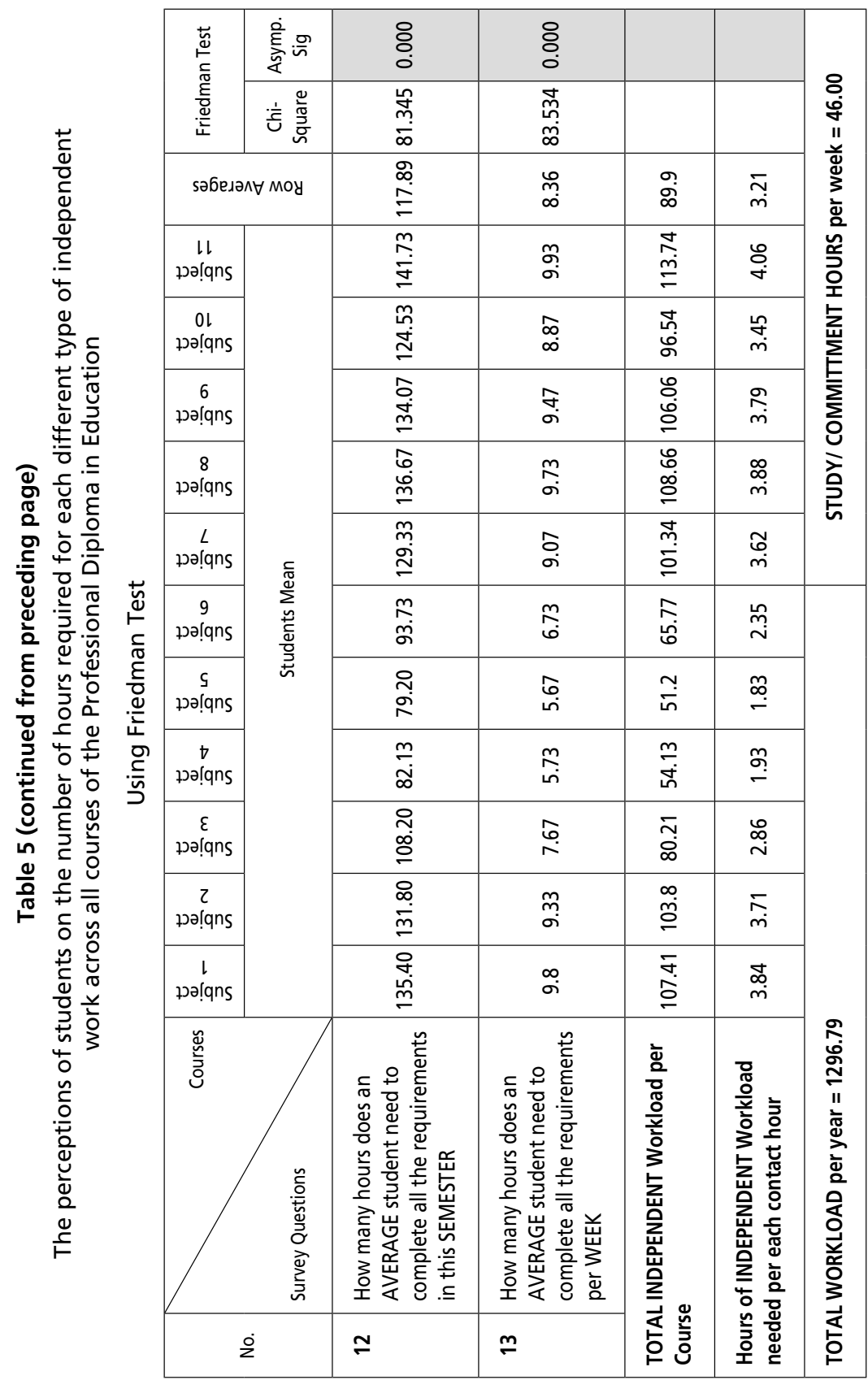


Friedman tests the Null hypothesis that k related variables come from the same population. For each case, the $\mathrm{k}$ variables are ranked from 1 to $\mathrm{k}$. Here are the Null and Alternate Hypotheses which were tested using Friedman Test.

$H_{\mathrm{o}}$ : The perceptions of students are equal in all samples.

$H_{1}:$ At least one of the perceptions of students is different (drawn from different population).

The above highlighted cells in Table 5 indicate significant differences between the perceptions of students on the number of hours required for each different type of independent work across different courses.

It is clear that there are significant differences between the perceptions of students on the number of hours required for each different type of independent work across different courses, with the highest average of estimations of the number of hours was given to course N. 11 "World Trends in Quality Assurance Systems", whereas the lowest average was given to course N. 5 "Assessment of Quality in Educational Institutions" across all different types of independent work except "preparation and follow-up work for scheduled classes".

Concerning "reading material", the highest average was given to course N. 11 (32.87), whereas the lowest average was given to course N. 5 (0). Concerning "preparation of assignments", the highest average was given to course N. 11 (28.33), whereas the lowest average was given to courses N. 4 "Educational Research" and N. 5 (0 and 0). Concerning "the number of hours an average student needs to complete all the requirements across the semester", the highest average was given to course N. 11 (141.7), whereas the lowest average was given to course N. 5 (79.3). Concerning "the number of hours an average student needs to complete all the requirements per week", the highest average was given to course N. 11 (9.93), whereas the lowest average was given to course N. 5 (5.67). As for "preparation and follow-up work for scheduled classes", the highest average was given to courses N. 7 "Approaches to School Enhancement" and N. 8 "Preparing Students for Knowledge Society" (20.53), whereas the lowest average was given to courses N. 3 "Quality Assurance Management in Education" and N. 4 (5.87 and 6.93 consecutively).

These findings lead us to reject the Null Hypothesis and accept the Alternate Hypothesis as Friedman Test has proved that there are significant differences between the perceptions of students on the number of hours required for each different type of independent work across all courses of the Professional Diploma in Education. 
Looking at the internal consistency of students' estimation of independent work hours required for one contact hour across courses of the Diploma as shown in the last row of Table 5, there is an obvious heterogeneity in the data. The estimated number of independent work hours required to the students for one contact hour ranges from 1.83 to 4.06 hours with an average of 3.21 of independent work hours required for each contact hour. This finding indicates that - according to students - some courses require more independent workload than others. For instance, whereas students need to spend 4 hours of independent work for one contact hour in course N. 11, they spend less than 2 hours of independent work for one contact hour in courses N. 4 and N. 5. This means that Course N. 11 requires double the number of hours of independent work required to Courses N. $4 \&$ N. 5. As shown previously in Table 2, the independent workload as estimated by academics was $62 \%$ of students' estimation. This implies that the number of hours for independent workload as estimated by academics is - on the average - only 2.0 for one contact hour whereas the number of hours for independent work as estimated by students is - as an average -3.21 for each contact hour, even though it ranges from 1.83 to 4.06 hours according to the given course. These findings can be very useful in the collegial discussions within the group of academics teaching in that Professional Diploma in Education to allow them the opportunity to discuss and negotiate one of the most important parameters about Credit Systems.

A couple of key parameters in the comparative debate about Credit Systems, i.e. annual and weekly student workload, are shown in Table 6 which gives a summary of workload hours as perceived by students and academics. Moreover, the ECTS credits corresponding to the annual workload could be easily inferred from the first data row (students' data).

\section{Table 6}

A Summary of Workload Hours as perceived by Students and Academics

\begin{tabular}{|l|l|c|c|c|}
\cline { 2 - 5 } \multicolumn{1}{c|}{} & \multicolumn{1}{|c|}{$\begin{array}{c}\text { WORKLOAD Hours as perceived } \\
\text { by survey data }\end{array}$} & $\begin{array}{c}\text { Contact } \\
\text { Hours }\end{array}$ & $\begin{array}{c}\text { Hours of } \\
\text { independent } \\
\text { work }\end{array}$ & Total \\
\hline Students & Annual Workload & $\mathbf{3 0 8 . 0 0}$ & $\mathbf{9 8 8 . 8 6}$ & $\mathbf{1 2 9 6 . 8}$ \\
\cline { 2 - 5 } & $\begin{array}{l}\text { Workload per week }(1 \mathrm{st} \\
\text { Semester, courses: 1,2,4,6,8,10). }\end{array}$ & 12.00 & 38.31 & 50.3 \\
\cline { 2 - 5 } & $\begin{array}{l}\text { Workload per week }(2 \mathrm{nd} \\
\text { Semester, courses: 3,5,7,9,11). }\end{array}$ & 10.00 & 32.33 & 42.3 \\
\hline Academics & Annual Workload & $\mathbf{3 0 8 . 0 0}$ & $\mathbf{6 1 0 . 0 4}$ & $\mathbf{9 1 8 . 0}$ \\
\hline
\end{tabular}


As a matter of fact, the students' data seem reasonable numbers (308 Contact Hours and 988.86 hours of independent work), even though the total annual workload (1296.8) is lower than the average point of several Tuning Europe surveys, which - as already stated above - is around a total of 1500 hours per year. ${ }^{29}$ It can be argued that this lower number is clearly related to a shorter academic year duration of this particular degree-course, i.e. 28-32 weeks whereas in Europe for usual degree-courses, the duration of the academic year ranges from 34 to 40). Indeed, the number of hours per week in TABLE 6 turns out to be higher (42-50 hours per week) than the number usually accepted in Europe (40-42 hours per week). This latter finding might be due either to a more intense learning approach of the Programme itself or to a "weak/excessive" overestimation made by the students. In that respect, it should be noted that student workload is not currently taken into account at Faculty of Education - Alexandria University and that this was the firsthand experience for those students to be asked about their perceptions on student workload. Therefore, there is a possibility for improvement.

Again, for the sake of comparative and common debate, the data in Table 6 allow in principle the calculation of the number of hours corresponding to one ECTS credit, as defined in the European Higher Education Area. This can be simply done, dividing the total annual workload by 60 . The students' data yield 21.6 hours whereas academics' data show that one ECTS credit equals 15.3 hours. This latter seems excessively low, when compared to the average of 25 hours corresponding to one ECTS credit in most European degree-courses. ${ }^{30}$

These findings, again, indicate that there are no unified regulations among academics for the estimation/allocation of student workload. It also shows that the process of estimating student workload in Credit Hour System at Alexandria University is staff-centred rather than student oriented. It is also indicated that there is marginal coordination between academics teaching in the same programme. This is made clear in Table 5 where the highest average of estimations of the number of hours was given to course N. 11 and the lowest average was given to course N. 4 across almost all different types of independent work.

\section{Concluding remarks}

The main findings show significant gaps between the perceptions of academics and students on student workload almost across all courses of the

${ }^{29}$ González and Wagenaar, eds., Tuning Educational Structures in Europe II, 382.

${ }^{30}$ Ibid. 
"Professional Diploma in Education" (the programme under investigation), where students' estimation of the number of hours needed to complete the independent work across all courses during the semester were much higher than that of academics except for fieldwork (site visits).

Significant differences were found between the perceptions of students on the number of hours required for each different type of independent work across different courses, with the highest average of estimations of the number of hours was given to course N. 11, whereas the lowest average was given to course N. 5 across all different types of independent work except "preparation and follow-up work for scheduled classes".

Only $36.4 \%$ of academics have taken students' feedback on workload into account when planning the workload for their courses. It was also found that $92 \%$ of students were not informed about the number of hours planned for independent work at the beginning of the course. In addition, $88 \%$ of students were not given the opportunity to express their feedback about workload.

These findings indicate that there are no unified regulations among academics to the estimation of student workload. It is also made clear that the process of estimating student workload in Credit Hour System at Alexandria University is staff-centred rather than student oriented as the majority of academics follow traditional methodologies in their estimation of student workload and $63.6 \%$ of academics never took students' feedback on workload into consideration when planning their courses. It is also enunciated clearly that there is marginal coordination between academics teaching in the same programme. It can be concluded that student voice about their workload is not adequately considered as their feedback is not taken into account, which can be interpreted in light of the absence of a "paradigm shift" from staffcentred to student oriented approaches to the estimation of student workload. Accordingly, there is a fundamental need for a way forward to highlight the needed paradigm shift.

\section{The Way forward: implications for policy and practice}

Based on the analysis and discussion of key findings of the study and through the insights from a comparative perspective that can arise from a careful process of policy learning, this section draws out their emergent implications for policy and practice to enhance the process of determining student workload in Higher Education in Egypt, as indicated earlier in the third research question: "What are the foreseeable implications - according to study findings - for policy and practice?" 
There is an indication that effort and intentional strategies should be put in place to minimize the gaps between the perceptions of academics and students on student workload. This calls for the adoption of a "paradigm shift" from input and staff-centred programmes to output and student oriented ones. In order to achieve such a "paradigm shift", several actions concerning policy and practice should be promoted. Among them, the study proposes:

- There should be a unified Credit System which could facilitate student mobility from a university to another in Egypt and to provide transparency and fairness to students. It should be comparable to other African universities to facilitate the compatibility and harmonization process and student and staff mobility at the continental level.

- Moving from Credit (teaching) Hour System to a Credit System similar to ECTS where the focus is on the student workload required to achieve the objectives of a programme, objectives specified in terms of the learning outcomes and the required competences.

- There should be coordination and cooperation between academics teaching in the same programme in terms of determining student workload.

- Rethinking about the revised programme "Professional Diploma in Education entitled: Quality of Educational Systems and Academic Accreditation" taking into account the necessity of informing students about the number of hours planned for independent work at the beginning of the course, taking their feedback and making decisions on and adjustment of the student workload accordingly. Students' feedback at the beginning of the academic year would be difficult on the side of the students - who have not yet gone through the needed learning activity but it would be relatively helpful as academics can do minor changes/ adjustments to their estimation of student workload. However, for this task to be done properly, academics have first to collect the data through the whole academic year since students can give feedback only after having gone throughout the whole process. At this point, academics can adjust/negotiate their estimates of student workload, which would be presented at the beginning of the new academic year. The study proposes using the two forms offered by the Tuning Approach for determining student workload in Higher Education programmes for that purpose. ${ }^{31}$

- Students, alongside academics, should have a crucial role in the monitoring process to determine whether the estimated student workload is realistic.

${ }^{31}$ González and Wagenaar, eds., Tuning Educational Structures in Europe II, 167-176. 
Last, but not least, the proposed implications for Policy and Practice provided for the researcher's own university might be of relevance for other universities in Egypt and for other countries having similar educational context. Finally, working according to a new paradigm or coping with a new paradigm requires time and effort but the outcome would be worthwhile, hopefully in respect of enhancing the process of determining student workload in Egyptian higher education.

\section{Bibliography}

“ECTS User's Guide.” Accessed September 10,2016, https://ec.europa.eu/education/ sites/education/files/ects-users-guide_en.pdf.

Alexandria University. "Alexandria University's Branch in Republic of Chad." Accessed June 1, 2016. http://www.portal.alexu.edu.eg/index.php/en/about-au/ branches/chad.

__. "Alexandria University's Branch in Sudan." Accessed June 1, 2016. http:// www.portal.alexu.edu.eg/index.php/en/about-au/branches/south-sudan-2.

Altbach, Philip. "Measuring academic progress: the course-credit system in American higher education." Higher Education Policy 14 (2001): 37-44.

Cohen, Louis, Lawrence Manion, and Keith Morrison. Research Methods in Education. 6th edition. London: Routledge, 2007.

Dallal, G. E., and L. Wilkinson. "An analytic approximation to the distribution of Lilliefor's test statistic for normality." The American Statistician, 40, no. 4 (1986): 294-296 (Correction: 41: 248).

Denzin, K. Norman, and Yvonna S. Lincoln. Handbook of Qualitative Research. London: Sage, 2002.

González, Julia, and Robert Wagenaar, eds. Tuning Educational Structures in Europe II. Universities' contribution to the Bologna Process. Bilbao: University of Deusto Press, 2005.

Kis, Viktoria. "Quality Assurance in Tertiary Education: Current Practices in OECD Countries and a Literature Review on Potential Effects." Paper presented as a contribution to the OECD Thematic Review of Tertiary Education, 2005. Accessed July, 1 2012, http://www.oecd.org/dataoecd/55/30/38006910.pdf.

Mackenzie, Noella, and Sally Knipe. "Research Dilemmas: Paradigms, Methods and Methodology." Issues In Educational Research 16, no. 2 (2006): 193-205.

Meyer, Benedichte Christine. "A Case in Case Study Methodology." Field Methods 13, no. 4 (2001): 329-325.

Noda, Ayaka. "How Do Credit Hours Assure the Quality of Higher Education? Time-Based vs. Competency-Based Debate." CEAFJP Discussion Paper Series 16-05, Centre d'Etudes Avancees Franco-Japonais de Paris (2016): 1-18.

Siegel, S., and N. J. Castellan. Nonparametric statistics for the behavioral sciences. New York: McGraw-Hill, Inc., 1988. 
Stensaker, Bjrn. "Trance, Transparency and Transformation: the impact of external quality monitoring on higher education." Quality in Higher Education 9, no. 2 (2003): 151-159.

Supreme Council of Universities - Sector Committee for Education. Student Guide for postgraduate studies according to Credit Hour System. Alexandria: El Gomhoreya Press, 2010.

Supreme Council of Universities. "Responsibilities of the SCU." Accessed March 1, 2016. http://portal.scu.eun.eg/Responsiblities.html.

Tuning Africa - II. "What is Tuning Africa?" Accessed March 20, 2016. http:// tuningafrica.org/en/what-is-tuning-africa.

_. "Second general meeting. Addis Ababa, 29 February - 2 March.” Accessed March 20, 2016. http://tuningafrica.org/upload/evento/editor/doc/2/booklet_ teacher-education_english.pdf.

Wagenaar, Robert. "Educational structures, learning outcomes, workload and the calculation of ECTS credits." In Tuning Educational Structures in Europe. Universities' contribution to the Bologna Process. An introduction, $2^{\text {nd }}$ edition, edited by Julia González and Robert Wagenaar, 57-81. Bilbao: University of Deusto Press, 2008.

Yin, K. Robert. Case Study Research: Design and Methods. 3rd edition. London: SAGE, 2003.

\section{About the Author}

SAEED ALSHAMY (saeed.alshamy@edu.alexu.edu.eg; saeed.alshamy@gmail. com) is an assistant professor at Foundations of Education Department, Faculty of Education, Alexandria University, Egypt. He holds PGCE and PhD in Education from University of Birmingham (UK). His PhD dissertation mainly addresses global trends in funding mechanisms and quality assurance systems in higher education. His principal research interests include: educational policy, comparative and international education, funding mechanisms, quality assurance systems, assessment and evaluation in higher education, competence-based learning, educational research, educational leadership and change management. 


\section{Annexes}

\section{Annex I Questionnaire for Academics}

Dear Colleague,

This study is part of the Tuning Africa II project. We are conducting a survey to estimate the workload of students by collecting information from ACADEMICS and STUDENTS. Please fill out the form and answer the questions in the unit/course/module which was taught by you during the last academic year. The collected data will be totally anonymous and confidential.

The project Tuning Africa II appreciates your collaboration in providing us with this information.

Instructions for completion:

Each University has informed Points 1-9 by 30 March 2016. You are invited to respond to the items 10-15. Please underline or circle one answer ("Yes" or "No"), if answer is "Yes" please specify the amount of time.

1. Subject area:

2. University:

3. Programme:

4. Semester/year ${ }^{32}$ :

5. Unit/Course/Module:

6. Number of calendar weeks in the semester:

7. Academic hour in your university is minutes.

8. Number of credits per year (if applicable):

9. Number of hours per credit (if applicable):

10. How many CONTACT HOURS ${ }^{33}$ in total are there in your unit/course/module during the SEMESTER?

32 Only in case semesters are not equal in duration or in case of a trimester system you are asked to respond to this item for a full academic year.

${ }^{33}$ Contact hours represent the amount of time spent on face to face teaching in a particular unit/course/module (Including lectures, seminars, clinical practices, supervised labs, project work and field work) as well as on-line interaction in the framework of a learning module and personal counselling. 


\begin{tabular}{|c|c|c|c|}
\hline 11. & $\begin{array}{l}\text { From the list below, specify the types of } \\
\text { INDEPENDENT WORK you require in the } \\
\text { unit/course/module during the SEMESTER. } \\
\text { Enter the estimated number of hours which, } \\
\text { in your opinion, the student should spend in } \\
\text { order to complete the independent study in } \\
\text { the unit/course/module. }\end{array}$ & __ hours & \\
\hline a. & Reading materials (including internet search) & Yes, __ hours & No \\
\hline b. & Fieldwork (site visits, etc.) & Yes, __ hours & No \\
\hline c. & $\begin{array}{l}\text { Laboratory work (not counting in contact } \\
\text { hours) }\end{array}$ & Yes, __ hours & No \\
\hline d. & $\begin{array}{l}\text { Preparation of assignments (essays, reports, } \\
\text { design work, modelling, interviews, } \\
\text { presentations, etc.) }\end{array}$ & Yes, __ hours & No \\
\hline e. & $\begin{array}{l}\text { Preparation and follow- up work for scheduled } \\
\text { classes }\end{array}$ & Yes, __ hours & No \\
\hline f. & $\begin{array}{l}\text { Preparation for assessment, final examinations, } \\
\text { tests, etc. (summative assessment). }\end{array}$ & Yes, __ hours & No \\
\hline g. & Other (specify): & _ hours & No \\
\hline 12. & $\begin{array}{l}\text { How many hours does an AVERAGE student } \\
\text { need to complete all the requirements of } \\
\text { your unit/course/module in this SEMESTER } \\
\text { (taking into account CONTACT HOURS } \\
\text { and INDEPENDENT WORK)? }\end{array}$ & __ hours & \\
\hline 13. & $\begin{array}{l}\text { How many hours does an AVERAGE } \\
\text { student need to complete all the requirements } \\
\text { of your unit/course/module per WEEK } \\
\text { (taking into account CONTACT HOURS } \\
\text { and INDEPENDENT WORK)? }\end{array}$ & & \\
\hline 14. & $\begin{array}{l}\text { When planning your unit/course/module, } \\
\text { did you estimate the hours students will } \\
\text { have to spend on independent work? }\end{array}$ & Yes & No \\
\hline 15. & $\begin{array}{l}\text { Did you take students' feedback on workload } \\
\text { into consideration when planning the } \\
\text { workload for your course? }\end{array}$ & Yes & No \\
\hline
\end{tabular}

Thank you for participating in the survey. 


\section{Annex II Questionnaire for Students}

Dear,

This study is part of the Tuning Africa II project. We are conducting a survey to estimate the actual workload of students by collecting information from ACADEMICS and STUDENTS. Please fill out the form and answer the questions in the unit/course/module that you have studied, finalized and passed in the last academic year. The data collected will be totally anonymous and confidential.

The project Tuning Africa II appreciates your collaboration in providing us with this information.

Instructions for completion:

Points 1-9 are pre-filled by the university staff. You need to respond to the items 10-15. Please underline or circle one answer ("Yes" or "No", if answer is "Yes" please specify the amount of time.

1. Subject area:

2. University:

3. Programme:

4. Semester/year ${ }^{34}$ :

5. Unit/Course/Module:

6. Number of calendar weeks in the semester:

7. Academic hour in your university is minutes.

8. Number of credits per year (if applicable):

9. Number of hours per credit (if applicable):

10. How many CONTACT HOURS ${ }^{35}$ in total were you given to study this unit/course/ module during the SEMESTER? hours

${ }^{34}$ Only in case semesters are not equal in duration or in case of a trimester system you are asked to respond to this item for a full academic year.

${ }^{35}$ Contact hours represent the amount of time spent on face to face teaching in a particular unit/course/module. (including lectures, seminars, clinical practices, supervised labs, project work and field work) as well as on-line interaction in the framework of a learning module and personal counselling. 


\begin{tabular}{|c|c|c|c|}
\hline 11. & $\begin{array}{l}\text { Using the list below, specify the types of } \\
\text { INDEPENDENT WORK you used in the } \\
\text { unit/course/module duringtheSEMESTER. } \\
\text { Under g. add any other ways of learning that } \\
\text { you use that are not included here. } \\
\text { Enter the estimated number of hours that } \\
\text { you needed to complete the independent } \\
\text { work on unit/course/module. }\end{array}$ & __ hours & \\
\hline a. & Reading materials (including internet search) & Yes, __ hours & No \\
\hline b. & Fieldwork (site visits, etc.) & Yes, ___ hours & No \\
\hline c. & $\begin{array}{l}\text { Laboratory work (not counting in contact } \\
\text { hours) }\end{array}$ & Yes, __ hours & No \\
\hline d. & $\begin{array}{l}\text { Preparation of assignments (essays, reports, } \\
\text { design work, modelling, interviews, } \\
\text { presentations, etc.) }\end{array}$ & Yes, __ hours & No \\
\hline e. & $\begin{array}{l}\text { Preparation and follow- up work for scheduled } \\
\text { classes }\end{array}$ & Yes, ___ hours & No \\
\hline f. & $\begin{array}{l}\text { Preparing for assessment final examinations, } \\
\text { tests, etc. (summative assessment). }\end{array}$ & Yes, __ hours & No \\
\hline g. & Other (specify): & _ hours & No \\
\hline 12. & $\begin{array}{l}\text { How many hours did you spend in the } \\
\text { SEMESTER tocompleteall the requirements } \\
\text { of this unit/course/module (taking into } \\
\text { account CONTACT HOURS and } \\
\text { INDEPENDENT WORK)? }\end{array}$ & __ hours & \\
\hline 13. & $\begin{array}{l}\text { How many hours per WEEK did you spend } \\
\text { (both CONT A C T HOURS AN D } \\
\text { INDEPENDENT WORK) to complete all } \\
\text { the requirements of this unit/course/module? }\end{array}$ & & \\
\hline 14. & $\begin{array}{l}\text { At the beginning of the unit/course/module, } \\
\text { were you informed about the number of } \\
\text { hours planned for independent work? }\end{array}$ & Yes & No \\
\hline 15. & $\begin{array}{l}\text { Were you given the opportunity to provide } \\
\text { feedback about the workload in this unit/ } \\
\text { course/module? }\end{array}$ & Yes & No \\
\hline
\end{tabular}

Thank you for participating in the survey. 


\title{
Credit Hour System and Student Workload at Alexandria University: a possible paradigm shift
}

\author{
Alsaeed Alshamy
}

\section{Copyright}

Copyright for this article is retained by the Publisher. It is an Open Access material that is free for download, distribution, and or reuse in any medium only for non-commercial purposes; provided any applicable legislation is respected, the original work is properly cited, and any changes to the original are clearly indicated. 